\title{
Characterization of a bacterial collar and rhizome rot of banana (M usa paradisiaca) caused by strains of Erwinia chrysanthemi pv. paradisiaca
}

\author{
Dipak T. Nagrale1, 2*, Sur esh G. B orkar ${ }^{1}$, Shailesh P. G awande ${ }^{1,4}$, A sit K . M andal ${ }^{3}$ and Satish A. \\ Raut $^{1}$
}

${ }^{1}$ Department of Plant Pathology and Agricultural Microbiology, Mahatma Phule Krishi Vidyapeeth, Rahuri-413722, Ahmednagar (M.S.), INDIA

${ }^{2}$ National Bureau of Agriculturally Important Microorganisms (NBAIM), Kusmaur, Maunath Bhanjan-275101 (U.P.), INDIA

${ }^{3}$ Directorate of Seed Research, Kushmaur, Maunath Bhanjan-275101 (U.P.), INDIA

${ }^{4}$ Ramie Research Station, CRIJAF (ICAR) Regional Station, Sorbhog-781317 (Assam), INDIA

*Corresponding author. E-mail: dip29unique@gmail.com

Received:September 15, 2013; Revised received: 0 ctober 16, 2013; Accepted: 0 ctober 20, 2013

\begin{abstract}
A serious collar and rhizome rot disease of banana was observed in the north region of Maharashtra state in post rainy season. The disease was caused by the bacterial strains of Erwinia chrysanthemi pv. paradisiaca identified and characterized by morphological, physiological, biochemical and pathogenicity tests. The infection occurred on new banana plantation of one month old in poorly drained soil. In post rainy season, banana plantations of 8 to 10 weeks were found severely infected. E. chrysanthemi pv. paradisiaca produced soft rot symptom on healthy banana rhizomes within three weeks. Two strains were isolated from the collar and rhizome rotted diseased samples which were similar in morphological, physiological and biochemical characteristics, however they differed in the virulence aggressiveness to cause the disease in banana. Strain II caused soft rot symptoms within 19 days, however strain I produced it within 23 days of inoculation with suspension of $3 \times 10^{8} \mathrm{CFU} \mathrm{ml}^{-1}$. The result of this study revealed that strain II was more aggressive as compared to strain I of E. chrysanthemi pv. paradisiaca.
\end{abstract}

Keywords: Banana, Erwinia chrysanthemi pv. paradisiaca, Rot, Strains

\section{INTRODUCTION}

Banana is a commonly eaten fruit of the herbaceous plant which belongs to the genus M usa. The crop is native to the tropical region of South-East Asia and Australia and now cultivated throughout the tropics (Stover and Simmonds, 1987). Banana (M usa spp.) is the fourth most important food commodity after rice, wheat and corn. It is produced in the tropical and subtropical regions of developing economies and India is the largest producer of banana in the world (FAO, 2009). The banana crop is affected by many diseases around the world. Among the bacterial diseases, bacterial wilt or moko disease (Pseudomonas solanacerum E.F. Smith) and tip over or soft rot disease [E rwinia carotovora (Jones Holland) Edward] causes significant losses to banana production (Chattopadhay, 1987; Stover, 2000; Jones, 2000; GomezCaicedo et al., 2001). But, nowadays the frequency of soft rot by Erwinia spp. has caused serious concern in banana cultivation in many tropical and subtropical countries (Manoranjitham et al., 2010; Singh et al., 2010; Thammaiah et al., 2010; Patel et al., 2011; Waman et al., 2012). A serious disease with new etiology i.e. the bacterial collar rot was observed in most of the field during post monsoon season in Jalgaon district of North region in Maharashtra state, where at least $5 \%$ plants were found infected in the field, which assumed significance and worries in the farmers. As the disease etiology was new, a detailed study of the disease and characterization of bacteria $E$. chrysanthemi pv. paradisiaca strains was undertaken.

\section{MATERIALS AND METHODS}

Source of bacterial isolates: The samples of banana showing typical symptoms of bacterial collar and rhizome rots were collected from different locations of banana growing areas of Jalgaon district of Maharashtra.

I solation and maintenance of isolates: The rhizome and collar rot affected samples of banana were collected for isolation from different locations of banana growing areas of Jalgaon district of Maharashtra. The affected part of the rhizome and pseudostem of banana was washed in the tap water, dried in blotter paper and then were cut into small pieces with a sterile scalpel and these were disinfected with mercuric chloride solution $(0.1 \%)$ for one minute and subsequently three washings were given in sterilized distilled water. The samples were dried by sterilized blotting paper. The small bit of sample were 
crushed in $5 \mathrm{ml}$ distilled sterilized water in the sterilized mortar and pestle and kept for 15 minutes to come out bacterial ooze. The isolation of rot causing bacteria was made by standard agar plate technique (APT) on nutrient agar (NA). The plates were then incubated at $27 \pm 1^{\circ} \mathrm{C}$ temperature. The growth of individual colonies of bacteria noticed after $24 \mathrm{hrs}$ of incubation was subsequently streaked on (NA) and sucrose peptone agar (SPA) plates for obtaining pure cultures. The pure cultures of the bacterial isolates thus obtained were maintained on NA slants in refrigerator at $4^{\circ} \mathrm{C}$ for further studies.

Pathogenicity test: The tissue culture banana saplings of cv. Grandnain were planted in earthen pots containing sterilized potting mixture of field soil, sand and compost in the ratio of 3:1:1 in glasshouse condition. The mixture was sterilized in the autoclave at $1.54 \mathrm{~kg} \mathrm{~cm}^{-2}$ for one $\mathrm{hr}$ for two consecutive days and filled in earthen pots. One sapling was planted in each pot. The pots in glasshouse were watered as and when required. At most care was taken to keep the plants healthy and succulent. The plants were fertilized with urea @ $5 \mathrm{~g} / \mathrm{plot}$ at weekly interval since the settlement of seedlings up to inoculation. One month old healthy banana saplings were used for proving the pathogenicity of the test bacteria $E$. chrysanthemi pv. paradisiaca. The pathogenicity of isolated bacteria was proved by hypodermic syringe method and method of Stover (1959). A bacterial suspension of $3 \times 10^{8} \mathrm{CFU} \mathrm{ml}$ ${ }^{1}$ was injected into the healthy rhizome by hypodermic syringe. Similarly sterilized pot soil was made sick with bacterial suspension by saturating the soil with bacterial inoculums. The observation on development of disease symptoms were noted every day. In another method of pathogenicity, banana rhizomes were washed and surface disinfected for 1 minute in $0.1 \% \mathrm{HgCl}_{2}$ solution. A plug of tissue was removed from the sterile rhizome to a depth of $3 \mathrm{~cm}$ with a sterile cork borer. A piece of nutrient agar culture of 3-4 mm square having $48 \mathrm{hr}$ bacterial growth was placed at the base of the wound and the plug was reinserted. The wound was then coated with paraffin and the rhizomes were planted in sterilized soil. In the check treatments, a piece of nutrient agar alone was inserted in the wound. The rhizomes were removed 21 days after planting, cut open and examined.

Potato soft rot test: Both the distinct bacterial strains purified from the isolated colonies were tested for their ability to cause soft rot on potato (Lelliot et al., 1966). Potato tubers were sterilized with $70 \%$ ethyl alcohol, rinsed with sterile distilled water, and aseptically cut into $1 \mathrm{~cm}$ slices. The potato slices were put in petri dishes containing sterilized filter paper impregnated with $2 \mathrm{ml}$ of sterile distilled water. Three replications were kept for each strain of rhizome and collar rot bacteria. The potato slices were inoculated with sterile needle pricking method. The inoculated slices were maintained in moistened petri dishes according to Togashi (1988) and Nabhan et al. (2006) and incubated at $30^{\circ} \mathrm{C}$ for 2 to 3 days. The bacterial strains that produced characteristic symptoms of soft rot on potato slices were selected and preserved in test tubes on NA media at $4^{\circ} \mathrm{C}$ in a refrigerator for further studies.

Reisolation of rhizome and collar rot bacteria: Reisolations for bacterial strains from inoculated diseased banana rhizomes and pseudostem were performed as described (Stover, 1959; Nagaraj et al., 2012).

Character ization of rhizome and collar rot bacteria: The standard methods in Bergey's manual of determinative bacteriology and differentiation test of plant pathogenic bacteria were perform to characterize the bacterial strains according to standard morphological, physiological, biochemical tests and pathovar group (Bradbury,1986).

\section{RESULTS}

Incidence of collar rots disease in banana growing tract of north M aharashtra: The collar and rhizome rot disease was reported for first time in farmer's field during 20062007 and attracted the attention of banana growers and scientist. The field visit and survey was carried out during 2008-2011 indicated that the incidence of the disease was more in Raver taluka as compared to Yawal and Chopda taluka. The average percentage of the incidence of collar rot disease was 5 to 7 per cent in the field.

Field symptoms of the disease: The infection occurred on new banana plantation of one month age in poorly drained soils. In post rainy season, banana plantation of 8-12 weeks was found severely infected. The symptoms includes initial yellowing of the young leaves which became lusterless and wither slowly followed by the characteristic blackening and rotting of central leaves and peripheral leaves appeared as withered. The rotting progressed upward in the pseudostem destroying leaf bases and decay of the plant. The infected plant can be easily pulled out from rotted collar region of plant with offensive and disagreeable odour (Fig.1).

I solation of causal bacteria, pathogenicity and reisolation of the pathogen isolation: Nutrient sucrose agar (NSA) plates were streaked with macerated diseased tissue of diseased rotted suckers and pseudostems, yielded two distinct types of bacterial colonies. One type of bacterial colonies were white, creamy, butyrous and produced the blue pigment after $72 \mathrm{hrs}$ while other type of bacterial colonies were white, creamy, raised dome shape and produced the blue pigment within $48 \mathrm{hrs}$. The bacterium produced the blue pigmentation after 2 days, a characteristic of $E$. chrysanthemi and was maintained as pure culture on NSA slants. These different two cultures or isolates were termed as E. chrysanthemi strain I and strain II, respectively.

I noculation of bacterial strains and its pathogenicity: 
Table 1. Morphological, physiological and biochemical characterization of rhizome and collar rot bacterial strains.

\begin{tabular}{|c|c|c|c|}
\hline \multirow{2}{*}{$\begin{array}{l}\text { S. } \\
\text { N. }\end{array}$} & \multirow{2}{*}{ Characteristics features } & \multicolumn{2}{|c|}{ E. chrysanthemi pv. paradisiaca } \\
\hline & & Strain I & Strain II \\
\hline 1 & Colony character & White, creamy, butyrous & White, creamy, dome shaped \\
\hline 2 & Gram reaction & - & - \\
\hline 3 & Glucose fermentation/OF & + & + \\
\hline 4 & Pits formation on CVP medium & + & + \\
\hline 5 & Pectate degradation & + & + \\
\hline 6 & Gas production from D-glucose & + & + \\
\hline 7 & Flagella & Peritrichous & Peritrichous \\
\hline 8 & Indigoidine/pigment production on YDC & Blue pigment at $72 \mathrm{hrs}$ & Blue pigment at $48 \mathrm{hrs}$ \\
\hline 9 & Indole production (from tryptophan) & + & + \\
\hline 10 & Tryptophan deaminase & - & - \\
\hline 11 & Lysine reduction & - & - \\
\hline 12 & Ornithine decarboxylases & - & - \\
\hline 13 & Reducing compounds from sucrose & $\mathrm{v}$ & $\mathrm{v}$ \\
\hline 14 & Growth at $36-37^{0} \mathrm{C}$ & + & + \\
\hline 15 & Growth at $40^{\circ} \mathrm{C}$ & - & - \\
\hline 16 & Arginine dehydrolase & - & - \\
\hline 17 & Growth in presence of $5 \% \mathrm{NaCl}$ & - & - \\
\hline 18 & $\mathrm{KCN}$ tolerance & - & - \\
\hline 19 & Production of levan & + & + \\
\hline 20 & Lecithinase activity & $\mathrm{v}$ & $\mathrm{v}$ \\
\hline 22 & Caesin hydrolysis & + & + \\
\hline 23 & Urease production & $\mathrm{v}$ & $\mathrm{v}$ \\
\hline 24 & Production of $\mathrm{H}_{2} \mathrm{~S}$ from cysteine & + & + \\
\hline 25 & Production of phosphatase & + & + \\
\hline 26 & Erythromycin sensitivity $(50 \mu \mathrm{g})$ & + & + \\
\hline 27 & Phenylanaline deaminease & + & + \\
\hline 28 & Caesin hydrolysis & + & + \\
\hline 29 & Oxidase & - & - \\
\hline 30 & Methyl Red test & - & - \\
\hline 31 & Catalase & + & + \\
\hline 32 & Acetoin production & + & + \\
\hline 33 & Gelatin liquefaction & - & - \\
\hline 34 & Growth on palatinose & - & - \\
\hline 35 & Tween 80 hydrolysis & + & + \\
\hline 36 & Sensitive to 2 units penicillin $G$ & + & + \\
\hline 37 & Urease production & - & - \\
\hline 38 & Nitrate reductase & + & + \\
\hline 39 & Hydrolysis of cotton seed oil & - & - \\
\hline 40 & Tobacco $(\mathrm{HR})$ test & + & + \\
\hline 41 & Pathogenicity to chrysanthemum & + & + \\
\hline
\end{tabular}

$*_{+=}$Positive, - =Negative, $\mathrm{v}=$ variable or weakly positive

The bacterial inoculation was carried out by hypodermic syringe infiltration method, sick soil culture method and method of Stover (1959). The collar region of the pseudostem showed blackening and collapsed at 19 days by E. chrysanthemi strain II while strain I took 23 days

for rhizome rotting, respectively. 8-12 weeks old banana plants showed typical pseudostem and rhizome rots by both the strains. The inoculated rhizomes after 21 days exhibited symptoms typical of rhizome rot around the area of inoculation. The rot spread over the inoculated 
Table 2. Utilization of organic compounds.

\begin{tabular}{llcc}
\hline S. & \multicolumn{3}{c}{ Utilization of or ganic compounds } \\
N. & Organic compounds & Strain I & Strain II \\
\hline 1 & Galacturonate & + & + \\
2 & Glycerate & + & + \\
3 & D(+) malate & + & + \\
4 & D(-) tartrate & + & + \\
5 & Malonate (ARJ medi um) & + & + \\
6 & 5-ketogluconate & + & + \\
7 & Citrate & + & + \\
8 & Cis-aconitate & - & - \\
\hline$*+=$
\end{tabular}

rhizome from the point of inoculation. Isolations from these rotted zone yielded pure cultures of the bacterium inoculated (Fig.2).

Reisolation: Reisolation from inoculated diseased banana rhizomes and pseudostem yielded the bacterial cultures which were identical to the original strains. I dentification and characterization of rhizome and collar rot bacterial strains: Based on differentiation test of plant pathogenic bacteria like gram reaction, utilization of glucose as oxidative, fermentative or inactive, flagellum characteristic, production of fluorescence pigment, reduction of nitrates, oxidase reaction and hypersensitive reaction on tobacco plant, the plant pathogenic bacteria were classified into genus and group. The test bacteria of collar rot disease, based on these tests were identified as Erwinia genus. The characterization of bacteria causing collar rot has been illustrated in the Tables 1- 3 .

\section{DISCUSSION}

Bacterial soft rot caused by E. carotovora and E. chrysanthemi, are among the most devastating diseases of vegetable and horticultural crops. Several other workers reported the symptoms of the disease as rhizome rot of banana (Tomlinson et al., 1987; Robinson and Mannicom, 1991; Akiew, 1998, Stover, 2000; Thwaites et al., 2000; soft rot of pseudostem (Chattopadhyay and Mukharjee, 1986; Pereira and Nunes, 1988; Guzman and Sandoval, 1996); watery rot of pseudostem (Rivera and Garcia, 1981); soft rot of banana (Chattopadhayay, 1987), root rot of banana and plantain (Figueroa, 1987) and vascular rot and wilt (Gomez-Caicedo et al, 2001). All these individual symptoms reported by various workers were observed as a rhizome; collar and pseudostem rot symptoms on banana in Jalgaon district. Several workers reported E. carotovora / E. chrysantheni pv. paradisiaca as the cause of this disease (Stover, 1959, Shillingford, 1974; Bhakthavathsalu et al., 1976; Rivera-Docando, 1978; Chattopadhayay and Mukharjee, 1986).

The bacterium associated with collar rot symptoms was identified as strain of .E. chrysanthemi pv. paradisiaca on the basis of morphological, physiological and biochemical characters of the bacterium and the pathogenic nature of the bacterium to cause collar rot symptoms. At least two distinct types of bacterial strains of this bacterium were isolated from the disease symptoms. The results regarding morphological features like butyrous colony character, gram negative rods, non spore former and peritrichous flagella correlated with Chattopadhayay and Mukherjee, 1986; Tomlinson and Cox,1987; Janse and Ruissen,1988; Mandal and Maiti, 2005). The blue pigmentation of bacteria matches with report of Hoitink and Daft (1972), Schaad and Brenner (1977). Similarly, the growth at $36-37^{\circ} \mathrm{C}$ were reported by Goto( 1979) Dicky and Victoria( 1980), Bradbury (1986), Tomlinson and Cox ( 1987) and Chellemi et al.(1998). No growth at $5 \%$ of the isolates exactly matches with results of Dicky and Victoria (1980), Tomlinson and Cox (1987), Janse and Ruissen (1988).

The positive levan formation reported by Hoitink and Daft (1972) and Mandal and Maiti (2005) matches with present result. Variable results were reported by Goto (1979) for rice strains of E. chrysanthemi for KCN

Table 3. Acid production from carbon sources.

\begin{tabular}{|c|c|c|c|}
\hline $\begin{array}{l}\text { S. } \\
\text { N. }\end{array}$ & Carbon sources & $\begin{array}{c}\text { Strain I } \\
7-12 \text { days }\end{array}$ & $\begin{array}{c}\text { Strain II } \\
7 \text { days }\end{array}$ \\
\hline 1 & $\beta$-lactose, trehalose & - & - \\
\hline 2 & $\alpha$-methyl glucoside & - & - \\
\hline 3 & $\mathrm{D}(-)$ Arabinose & + & + \\
\hline 4 & D(-) Mannitol & + & + \\
\hline 5 & Inulin & - & - \\
\hline 6 & $\mathrm{D}(+)$ Melibiose & + & + \\
\hline 7 & $\mathrm{D}(+)$ Fructose & + & + \\
\hline 8 & Maltose & + & + \\
\hline 9 & Cellobiose & + & + \\
\hline 10 & D-Raffinose & + & + \\
\hline 11 & Salicin & + & + \\
\hline 12 & Dulcitol & - & - \\
\hline 13 & Galactose & + & + \\
\hline 14 & Melizitose & - & - \\
\hline 15 & Inositol & + & + \\
\hline 16 & Palatinose & - & - \\
\hline 17 & Xylose & + & + \\
\hline 18 & Esculin & + & + \\
\hline 19 & Mannose & + & + \\
\hline 20 & Ribose & + & + \\
\hline 21 & Starch & $\mathrm{v}$ & $\mathrm{v}$ \\
\hline 22 & Adonitol & $\mathrm{v}$ & $\mathrm{v}$ \\
\hline 23 & Dextrin & + & + \\
\hline 24 & Rhamnose & + & + \\
\hline 25 & Sorbitol & 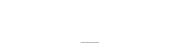 & 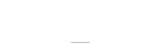 \\
\hline
\end{tabular}




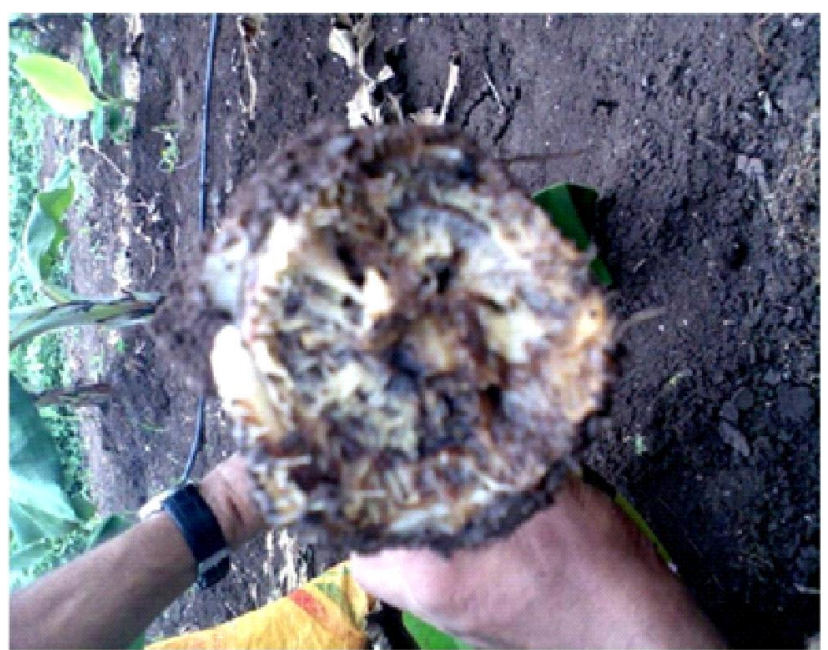

Fig.1. Field symptom of rhizome, collar and pseudostem rot of banana in post rainy season of banana plantation.

tolerance. However, in present study both strains showed negative result for $\mathrm{KCN}$ tolerance. Positive $\mathrm{H}_{2} \mathrm{~S}$ production was reported by Dickey and Victoria (1980) and Mandal and Maiti (2005) exactly matches with present result. Production of phosphatase and erythromycin sensitivity recorded by Dicky and Victoria (1980) and Tomlinson and Cox (1987) is exactly similar with the present result. Similarly, positive pectate degradation reported by McFadden (1969), Hoitink and Daft (1972), Dicky and Victoria (1980) strongly correlate with present result. Oxidase and urease tests in this study reported as negative are similar with Hoitink and Daft (1972) and Dicky (1979) .

The cotton seed oil hydrolysis test was reported as negative, exactly matches with result of Hildebrand and Schroth (1967). Potato soft rot test reported positive, exactly correlates with the result of Schaad and Brenner (1977), Togashi (1988), Nabhan et al.(2006) and Rahman et al.,(2012). In present study, acid and gas was produced from D (+) glucose, however, acid was produced only from D (-) arabinose, xylose, esculin, mannose, ribose, starch, adonitol and dextrin. Similar results were reported by Hoitink and Daf (1972), Schaad and Brenner (1977), Dickey (1979), Dickey and Victoria (1980) and Mandal and Maiti (2005). Both the soft rot bacteria strains utilized galacturonate, glycerate, D (+) malate, tartrate and malonate as organic compound. These results were congruence with the results of Thomson et al., (1977) Dickey and Victoria (1980), Bradbury (1986), Tomlinson and Cox (1987) and Janse and Ruissen (1988).

The carbon utilization test slightly differs from earlier reports indicating the new pathotype or biovar of $E$. chrysanthemi pv. paradisiaca. On the basis of pathogenicity study and characterization, it was found that strain II was more virulent and aggressive as compared to strain I. The collar rot disease symptoms in banana were produced in 19 days by strain II while strain

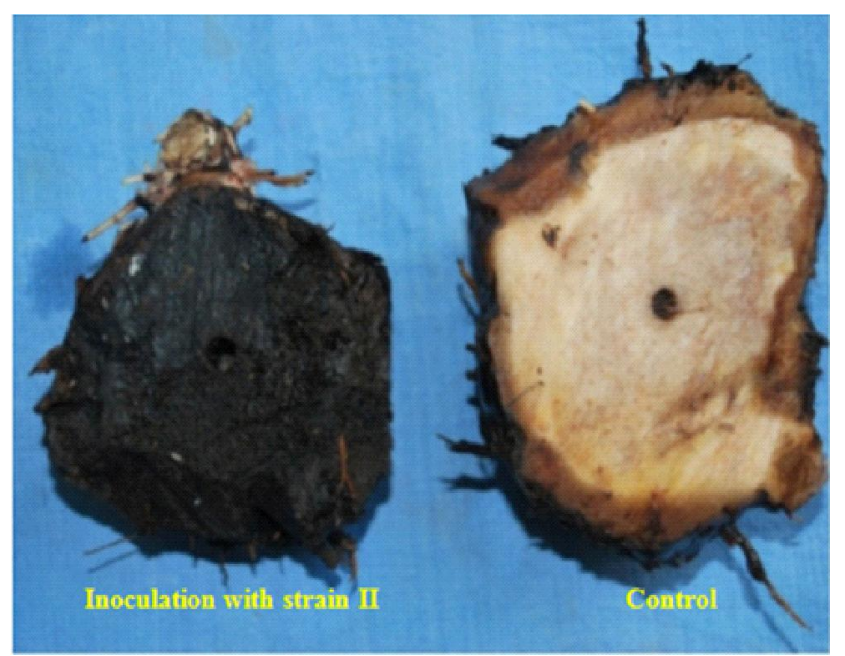

Fig.2. Rhizome rot of banana caused by strain II of E.chrysanthemi pv. paradisiaca (Stover, 1959).

I took 23 days for collar rot symptoms. The traditional method of characterization of pectinolytic erwinias are still very useful for the research on pathovar and host range studies.

\section{Conclusion}

The two pathogenic strains of E. chrysanthemi pv. paradisiaca were isolated from banana rhizomes and pseudostems which were identified as morphological, biochemical, symptomatological and pathogenicity tests. However, they were differed on blue pigmentation and aggressiveness to cause soft rot and disease symptoms. Strain II was more aggressive than strain I. Thus, there may be possibility of new biovar (s) in these isolated soft rotting erwinias. Thus further, extensive and critical biochemical, germplasm differential tests and molecular methods are needed to confirm the identity of these strains from north Maharashtra regions.

\section{REFERENCES}

Akiew, E. (1998). An evaluation of the relative importance of banana corn rot in North Queensland. HRDC Project No. FR 97030.

Bhakthavathsalu, C.M., Sathiamorthy, S. and Chockalingam, S. (1976). Bacterial head rot - A new disease in Nendran banana. Unda, 14 pp. Vellore, India, Tamil Nadu Department of Agriculture. CAB. Horticultural Abstracts 046-01659.

Bradbury, J.F. (1986). Erwinia: Guide to plant pathogenic bacteria, 61-79 pp. CAB International, Wallingford, UK.

Chattopadhayay, P.K. and Mukherjee, N. (1986). A pseudostem rot of banana due to E rwinia chrysanthemi pv. paradisica. Curr. Sci., 55(6): 789-790.

Chattopadhyay, P.K. (1987). Soft rot: A threat to banana cultivation in West Bengal. Indian H ort., 31(4): 9.

Chellemi, D.O., Dankers, H.A., Hill, K., Cullen, R.E., Simone, G.W., Gooch, M.D. and Allingham, J.E. (1998). Occurrence of bacterial stem rot, caused by Erwinia chrysanthemi, on field grown tomato in Florida. PI. Dis., 82(7): 831.

Dickey, R.S. (1979). Erwinia chrysanthemi: A comparative 
study of phenotypic properties from several hosts and other Erwinia species. Phytopath., 69: 324-329.

Dickey, R.S. and Victoria, J.I. (1980). Taxonomy and emended description of strains of Erwinia isolated from M usa paradisiaca Linnaeus. International J . Syst. Bacteriol., 30: 129-134.

FAO (2009). Banana Statistics (FAOSTAT). ftp://ftp.fao.org/ docrep/fao/meeting/018/k6853e.pdf.

Figueroa, L. (1987). Control of diseases and nematodes of banana and plantain. Revista M exicana-de-Fitopathologia., 5(2): 181-184.

Gomez-Caicedo, L.E., Echeverry, N.E. and Gonzalez, S.R. (2001). Evaluation of cultural, chemical and biological control of vascular rot and wilt in plantain (Musa AAB Simmonds). Montpelier, France: International Network for the Improvement of Banana and Plantain (INIBAP). Infomusa, 10(1): 17-21.

Goto, M. (1979). Bacterial foot rot disease of rice caused by strain of E rwinia chrysanthemi. Phytopath., 68: 213-216.

Guzman, M. and Sandoval, J. (1996). Symptoms of pseudo stem soft rot in the hybrids FHIA-01 and FHIA-02. Corbana., 21(46): 145-150.

Hildebrand, D.C. and Schroth, M.N. (1967). 'Drippy nut' of oak caused by E rwinia amylovora var. quercina. N ew Zeland J. Sci., 11: 590-607.

Hoitink, H.A.J. and Daft, G.C. (1972). Bacterial stem rot of poinsettia, a new disease caused by E rwinia carotovora var. chrysanthemi. Plant Dis. Rep., 56: 480-484.

Janse, J.D. and Ruissen, M.A. (1988). Characterization and classification of Erwinia chrysanthemi strains from several hosts in the Netherlands. Phytopath., 78: 800-808.

Jones, D. R. (2000). Diseases of Banana, Abaca and Enset. CABI Publishing, Wallingford, Oxon, UK.

Lelliot, R.A., Billing, E. and Hayward A.C. (1966). A determinative scheme for the Fluorescent Plant Pathogenic Pseudomonads. J. App. Bacteriol., 29: 70-489.

Mandal, K. and Maiti, S. (2005). Bacterial soft rot of aloe caused by Pectobacterium chrysanthemi: a new report from India. BSPP New Disease Reports Online [www.bspp. org.uk/publications/new-disease reports/ndr.php? id $=011001]$.

Manoranjitham, S. K., Seenivasan, N., Auxcilia, J., Durga Devi, D. and Sooriananthasundaram, K. (2010). In vitro and in vivo efficacy of biocontrol agents and antibiotic against Erwinia carotovora ssp. carotovora. In M. M. Mustaffa, K. N. Shiva, B. Padmanabhan and M. Mayil Vagnan (Eds.), Abstracts, G lobal conference on Banana, Tiruchirapalli, India (p. 104). Association for Improvement in Production and Utilisation of Banana (AIPUB) and the National Research Centre for Banana (NRCB).

McFadden, L.A. (1969). Aglaonema pictum a new host of Erwinia chrysantemi. Plant Dis. Rep., 53: 253-254.

Nabhan, S., Al-Chaabi, S. and Abu-Ghorrah, M. (2006). Evaluation of pathogenicity of different Erwinia isolates causal agents of potato soft rot and blackleg, and assessment of susceptibility of some potato cultivars under laboratory conditions. The Ninth Arab Congress of Plant Protection, 19-23 November 2006, Damascus, Syria.

Nagaraj, M.S., Umashankar, N., Palanna, K. B. and Khan, A.N.A. (2012). Etiology and management of tip over disease of banana by using biological agents. I.J .A.B.R., 2(3): 483-486.

Patel, P. R., Sharma, H. and Shukla, A. (2011). Efficacy of chemicals against rhizome rot of banana. Karnataka J ournal of Agricultural Sciences, 24 : 712-713.

Pereira, L.V. and Nunes, R.A.S. (1988). Soft rot of the rhizome and pseudostem of banana (M usa acuminata). Fitopathologia Brasileira., 13(1): 70-71.

Rahman, M. M., Ali, M. E., Khan, A. A., Hashim, U., Akanda, A. M. and Hakim M. A. (2012). Characterization and identification of soft rot bacterial pathogens in Bangladeshi potatoes. African J. M icrobiol. Res., 6(7):437-1445.

Rivera, N. and Garcia, A. (1981). Distribution in Cuba of watery rot of the pseudostem of banana caused by Erwinia chrysanthemi. Ciencia-Y-Tecnia-en-la-Agricultura, Protection de Plantas. 4(2/3): 89-96.

Rivera Docando, N. (1978). Comparative study of two new bacterial diseases in banana growing areas of Cuba. Agrotecnia-de-Cuba., 10(2): 35-44.

Robinson, J.C. and Manicom, B.Q. (1991). Rhizomes of new banana cultivars are susceptible to Erwinia corm rot. Inligtingsbulletin - Navorsingsinstituut-vir-sitrus-en subtropiese-Vruget. No. 228: 1-2.

Schaad, N.W. and Brenner, D. (1977). A bacterial wilt and root rot of sweet potato caused by Erwinia chrysanthemi. Phytopath., 67: 303-308.

Shillingford, C.A. (1974). Bacterial rhizome rot of banana in Jamaica. Plant Dis. Rep., 58: 214-218.

Singh, S. K., Ray, P. K. and Jha, P. K. (2010). Banana diseases in Bihar: the current scenario. In M. M. Mustaffa, K. N. Shiva, B. Padmanabhan and M. Mayil Vagnan (Eds.), Abstracts, G lobal conference on Banana, Tiruchirapalli, India (p. 103). Association for Improvement in Production and Utilisation of Banana (AIPUB) and the National Research Centre for Banana (NRCB).

Stover, R.H. (1959). Bacterial rhizome rot of bananas. Phytopath., 49: 290-292.

Stover, R.H. (2000). Diseases and other health problems in tropical Africa. Acta Horticulture, Leuven, Belgium: International Society for H orticultural Science (ISHS), 540: 311-317.

Stover, R. H. and Simmonds, N. W. (1987). Bananas. Third edition. Longman scientific/John wiley, New York, USA. pp. 468

Thammaiah, N., Kanamadi, V. C., Shirol, A. M., Kulkarni, M. S. and Swamy, G. S. K. (2010). Management of tip over disease of banana cv. Grand Naine. In M. M. Mustaffa, K. N. Shiva, B. Padmanabhan, and M. Mayil Vagnan (Eds.), Abstracts, G lobal conference on Banana, Tiruchirapalli, India (p. 106). Association for Improvement in Production and Utilisation of Banana (AIPUB) and the National Research Centre for Banana (NRCB).

Thomson, S.V., Schroth, M.N., Hills, F.J., Whitney, E.D. and Hildebrand, D.C. (1977). Bacterial vascular necrosis and root of sugarbeet. General description and etiology. Phytopath., 67: 1183-1189.

Thwaites, R., Eden-Green, S.J. and Black, R. (2000). Disease caused by bacteria. In Diseases of Banana, Abaca and Euset, D.R. Jones (ed.), Wallingford, U.K. CABI Publishing. pp. 213-239.

Togashi, J. (1988). Identification of the organisms causing the 
soft rot disease in vegetables in the fields of Tsuruaka district. Bull. Yamaga U niv. Agric. Sci., 10(3): 473-478.

Tomlinson, D.L. and Cox, P.G. (1987). A new disease of cardamom (Elettaria cardamomum) caused by Erwinia chrysanthemi in Papua New Guinea. Plant Pathol., 36: 79-83.

Tomlinson, D.L., King, G.A. and Ovia, A. (1987). Bacterial corn and rhizome rot of banana (M usa spp.) in Papua New
Guinea caused by Erwinia chrysanthemi. Tropical Pest Management., 33: 196-199.

Waman, A. A., Bohra, P., Umesha, K., Chandrashekar, S.C., Sathyanarayana, B.N. and Sreeramu, B.S. (2012). Successful rescue and field establishment of native banana varieties severely affected by rhizome rot. J. Agr. Rural D evelop. Trop. Subtrop., 113 (2):147-154. 